\title{
Question of Timber Sector Clustering: Results and Experience of Northern Countries
}

\author{
A. Plastinin \\ Northern (Arctic) Federal University (NARFU) \\ Arkhangelsk, Russia \\ a.plastinin@narfu.ru
}

\author{
O.Sushko \\ Northern (Arctic) Federal University (NARFU) \\ Arkhangelsk, Russia \\ o.sushko@narfu.ru
}

\begin{abstract}
Cluster-based development of various economic sectors is associated with benefits, provided by participants' interaction and integration of different activities: ongoing, investment, innovation. Cooperation provides the total synergy effect, cost minimization, higher profitability of business processes. The paper presents findings of the research undertaken to study transformation of the northern countries' timber sector. The analysis of the northern countries' experience and economic growth programmes shows that their economic stability is based on rational use of natural resources, first and foremost on renewable forest resources, while the timber industry is a major taxpayer and budget contributor. Cluster development of the northern countries' timber sector with high investment provides for production stability and high valueadded timber exports. Results of the timber sector development in Sweden, Finland, Canada, where forests represent more than a half of the area, are given as arguments. Despite natural and geographical features, hindering the forest exploitation, Norway has programmes of the timber sector support and development as well. High results of the northern countries are mainly related to the cluster-based approach to the sector management, including the innovational timber cluster establishment. The cluster-based development of the northern countries' timber sector with high investment provides for production stability and high value-added timber export. The northern countries' success in the timber sector attracts the attention of Russian timber companies, which have actively been initiating clustering over the last five years. The development of timber sector clusters in Russia will secure their integration in the global transnational processes of timber product value creation. It will result in the innovation level for the Russian enterprises' engineering capability and facilities, access to modern management methods and competitive global markets
\end{abstract}

Keywords - timber production, clusters, innovations, strategic forestry programmes, sustainable development of the Russian timber industry

\section{INTRODUCTION}

At present scholars from various countries show significant interest in studying processes, developing tools and methods, forecasting results and consequences of clustering in different spheres, branches of economy, regions. It is necessary to start the overview of the current research and developments, practical global experience with Europe, where cluster policy has a longer development period (since the 1970s-80s), and since 2000 the national programmes of cluster development have been devised [1]. The European Cluster Observatory reports that more than 2000 clusters operate in 28 European countries. The driving force for cluster development was the European cluster memorandum (2008), which determined the transition to promising European clusters' development policy to achieve the global leaders' level [2]. Cluster development of different economy branches builds on benefits, provided by participants' interaction, integration of a range of activities: ongoing, investment, innovation [3]. Cooperation provides the total synergy effect, cost minimization, higher profitability of business processes. Cluster development of the timber sector in northern countries with high investment provides for production stability and high value-added timber export. High results of the timber sector in Sweden, Finland, Canada, Norway are associated with the cluster-based approach to forest management, based on the integrated and innovational timber exploitation and environmentally friendly technologies.

\section{RESEARCH PROBLEMS AND METHODOLOGY}

\section{A. Problem statement}

The northern countries' success in the timber sector attracts the attention of Russian timber companies, horizontally and vertically integrated ones, which have actively been initiating clustering over the last five years. It should be noted that the development of timber sector clusters in Russia will secure their integration in the global transnational processes of timber product value creation (Food and Agriculture Organisation of the United Nations, 2012) [4]. It will result in the innovation level for the Russian enterprises' engineering capability and facilities, access to modern management methods and competitive global markets. This process is relevant given the uncertainty of timber and paper markets development, caused by unstable economic state of global consumers and demand fluctuations respectively.

\section{B. Research Questions}

The first stage of the research project 'Theoretical and methodological approaches of the timber cluster functioning as a tool for the Russian spatial development' included the analysis of production, export and import supplies of Swedish, 
Finnish, Canadian, Norwegian timber products from 1961 to the present day [5], the study of the Northern countries' cluster programmes, as well as of their impact on the timber sector development results was started.

\section{Research Questions}

Scientific findings, planned for this project research, incorporate identification and classification of key prerequisites and clustering factors for the Russian timber sector. An essential result of the project is justification of the clustering necessity as a factor for the state and economic activity subjects to liaise in the current market economy. The research significance involves assessment of the timber sector clustering opportunities, development of some algorithm to create innovational timber clusters, with horizontal and vertical connections of the cluster subjects' activities. The study is relevant in terms of inter-cluster interaction methodology development and mega-cluster establishment in the timber sector.

\section{RESULTS AND DISCUSSION OF THE STUDY}

The northern forest belt in subarctic countries covers areas of Finland, Sweden, Canada, Norway, where softwood prevails and is supplied as roundwood, processed to obtain planks, pulp, wood boards, cardboard, paper and other timber products [6] (Fig. 1). The forest area of the four leading timber producers covers 3.5 million $\mathrm{km}^{2}$, accounting for 11.5 per cent of the global forest land.

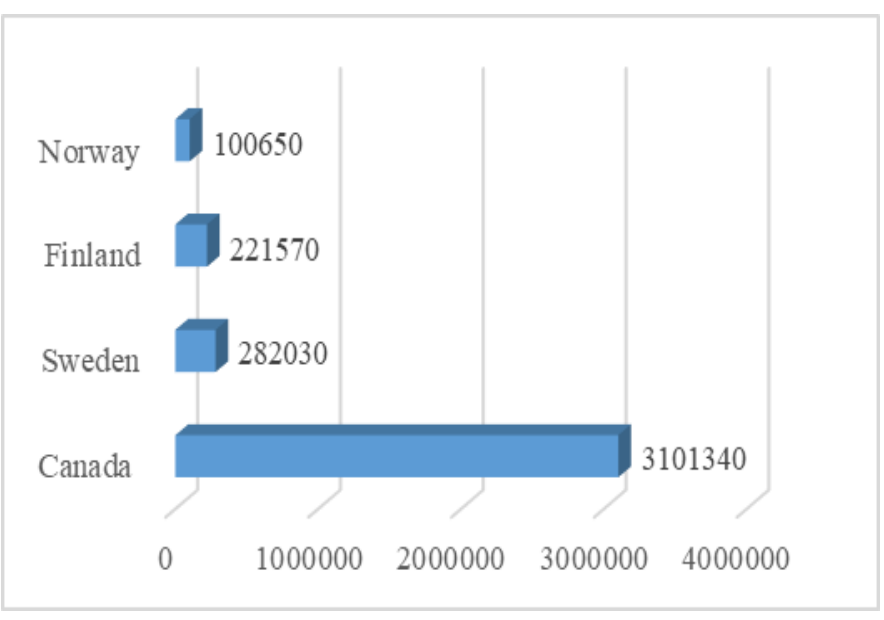

Fig. 1. Forest area in January 2018, thousand sq. m.

In Russia the forested area constitutes more than 49 per cent of its land (25 per cent of the world's forests) [2].

Despite significant forest resources, natural forested areas are diminishing, this fact is especially relevant for the northern countries with severe climate and nature conditions, as well as a more prolonged process of forest regeneration and growth. For instance, economists report that forest area has reduced by 50 per cent over the two hundred years [7]. The current situation regarding natural resources exploitation is changing, now productivity and forest regeneration are closely connected with the technical sophistication of production [8]. In the northern countries with the developed timber industry the natural regeneration of forests lagged behind the industrial exploitation, which resulted in the decrease of accessible and suitable woodland. Simultaneously, the timber industry is growing in economically developing countries, working with fast growing southern wood. Traditional leaders are more and more sidelined by Latin America (Brazil, Chile), Indonesia and South Africa, due to large resources of fast growing wood and low expenditure at the expense of extensive use of forest resources, which make products more cost-effective at the global market [9]. Under the circumstances of increased competitiveness at the global market European timber and pulp producers are united and develop innovation and intensification for forest resources processing together.

Thus, despite the increase in world production and exports of timber (Table. 1, 2), increased spatial competition by shifting the center of harvesting and processing of wood to the southern forest belt

TABLE I. WORLD TIMBER PRODUCTION

\begin{tabular}{|c|c|c|c|c|c|}
\hline \multirow{2}{*}{ Product } & \multirow{2}{*}{$\begin{array}{l}\text { unit } \\
\text { measure }\end{array}$} & \multirow[t]{2}{*}{2016} & \multicolumn{3}{|c|}{ Change (\%) compared to: } \\
\hline & & & 2015 & 2000 & 1980 \\
\hline Roundwood & million $\mathrm{m} 3$ & 3737 & $1 \%$ & $8 \%$ & $19 \%$ \\
\hline Fuelwood & million $\mathrm{m} 3$ & 1863 & $0 \%$ & $5 \%$ & $11 \%$ \\
\hline $\begin{array}{r}\text { Business } \\
\text { roundwood }\end{array}$ & million $\mathrm{m} 3$ & 1874 & $3 \%$ & $11 \%$ & $30 \%$ \\
\hline Wood pellets & $\begin{array}{c}\begin{array}{c}\text { million } \\
\text { tons }\end{array} \\
\end{array}$ & 29 & $6 \%$ & & \\
\hline Carving wood & million $\mathrm{m} 3$ & 468 & $3 \%$ & $21 \%$ & $11 \%$ \\
\hline $\begin{array}{l}\text { Engineered wood } \\
\text { products }\end{array}$ & million $\mathrm{m} 3$ & 416 & $4 \%$ & $123 \%$ & $310 \%$ \\
\hline $\begin{array}{r}\text { Veneer and } \\
\text { plywood }\end{array}$ & million $\mathrm{m} 3$ & 174 & $3 \%$ & $161 \%$ & $296 \%$ \\
\hline $\begin{array}{r}\text { OSB, particle } \\
\text { Board and } \\
\text { fibreboard }\end{array}$ & million $\mathrm{m} 3$ & 242 & $5 \%$ & $102 \%$ & $321 \%$ \\
\hline Wood pulp & $\begin{array}{c}\text { million } \\
\text { tons }\end{array}$ & 180 & $2 \%$ & $5 \%$ & $43 \%$ \\
\hline $\begin{array}{l}\text { Weight of non- } \\
\text { wood fiber }\end{array}$ & $\begin{array}{c}\text { million } \\
\text { tons }\end{array}$ & 12 & $-7 \%$ & $-19 \%$ & $70 \%$ \\
\hline Recovered paper & $\begin{array}{c}\text { million } \\
\text { tons }\end{array}$ & 230 & $1 \%$ & $60 \%$ & $354 \%$ \\
\hline $\begin{array}{l}\text { Paper and } \\
\text { cardboard }\end{array}$ & $\begin{array}{c}\text { million } \\
\text { tons }\end{array}$ & 409 & $0 \%$ & $26 \%$ & $142 \%$ \\
\hline
\end{tabular}

TABLE II. WORLD EXPORTS OF TIMBER

\begin{tabular}{|c|r|r|r|r|r|}
\hline \multirow{2}{*}{ Product } & \multirow{2}{*}{$\begin{array}{c}\text { unit } \\
\text { measure }\end{array}$} & 2016 & \multicolumn{3}{|c|}{ Change (\%) compared to: } \\
\cline { 4 - 6 } & & 2015 & 2000 & 1980 \\
\hline Roundwood & $\begin{array}{c}\text { million } \\
\mathrm{m} 3\end{array}$ & 132 & $2 \%$ & $11 \%$ & $40 \%$ \\
\hline Fuelwood & $\begin{array}{c}\text { million } \\
\mathrm{m} 3\end{array}$ & 9 & $-4 \%$ & $153 \%$ & $31 \%$ \\
\hline $\begin{array}{c}\text { Business } \\
\text { roundwood }\end{array}$ & $\begin{array}{c}\text { million } \\
\mathrm{m} 3\end{array}$ & 122 & $3 \%$ & $7 \%$ & $109 \%$ \\
\hline Wood pellets & $\begin{array}{c}\text { million } \\
\text { tons }\end{array}$ & 17 & $8 \%$ & & \\
\hline Carving wood & $\begin{array}{c}\text { million } \\
\mathrm{m} 3\end{array}$ & 147 & $7 \%$ & $28 \%$ & 1 \\
\hline
\end{tabular}




\begin{tabular}{|c|c|r|r|r|r|}
\hline $\begin{array}{c}\text { Engineered wood } \\
\text { products }\end{array}$ & $\begin{array}{c}\text { million } \\
\mathrm{m} 3\end{array}$ & 91 & $7 \%$ & $60 \%$ & $457 \%$ \\
\hline $\begin{array}{r}\text { Veneer and } \\
\text { plywood }\end{array}$ & $\begin{array}{c}\text { million } \\
\mathrm{m} 3\end{array}$ & 34 & $5 \%$ & $56 \%$ & $326 \%$ \\
\hline $\begin{array}{c}\text { OSB, particle } \\
\text { Board and } \\
\text { fibreboard }\end{array}$ & $\begin{array}{c}\text { million } \\
\mathrm{m} 3\end{array}$ & 57 & $8 \%$ & $62 \%$ & $585 \%$ \\
\hline $\begin{array}{c}\text { Wood pulp } \\
\begin{array}{c}\text { Weight of non- } \\
\text { wood fiber }\end{array}\end{array}$ & $\begin{array}{c}\text { million } \\
\text { tons }\end{array}$ & 0.4 & $-7 \%$ & $20 \%$ & $88 \%$ \\
\hline $\begin{array}{c}\text { Recovered paper } \\
\text { Paper and } \\
\text { tons } \\
\text { cardboard }\end{array}$ & $\begin{array}{c}\text { million } \\
\text { tons }\end{array}$ & 111 & $0 \%$ & $13 \%$ & $218 \%$ \\
\hline
\end{tabular}

While wood-working products output is increasing in the northern countries, from 1980 to the present day the growth rates are significantly lower than the global timber industry rates [10]. This fact is related to the above-mentioned processes, as well as with structural changes in logging and woodworking sectors production and decrease in pulp and paper industry competitiveness. The logging and wood-based products output has the most positive trend. For instance, wood production in the four northern countries (Canada, Sweden, Finland, Norway) accounted for 7.9 per cent of the global output in 1961, whereas in 2016 it reached 8.3 per cent (Fig. 2) [11].

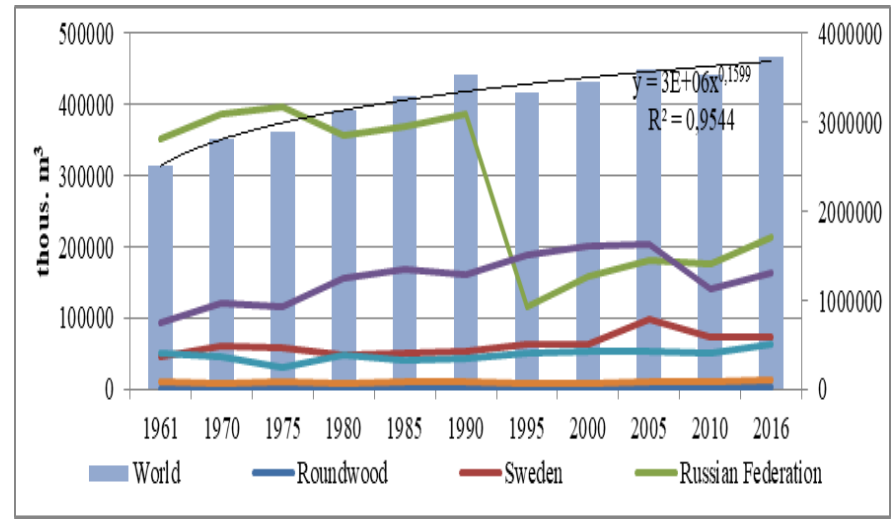

Fig. 2. Dynamics of wood production

In the northern countries sawn timber production demonstrates more active development over the 55-year period under consideration. In 1961 sawn timber output in the four countries accounted for 12 per cent of the world's total production, whereas in 2016 it reached 24 per cent (Fig. 3).

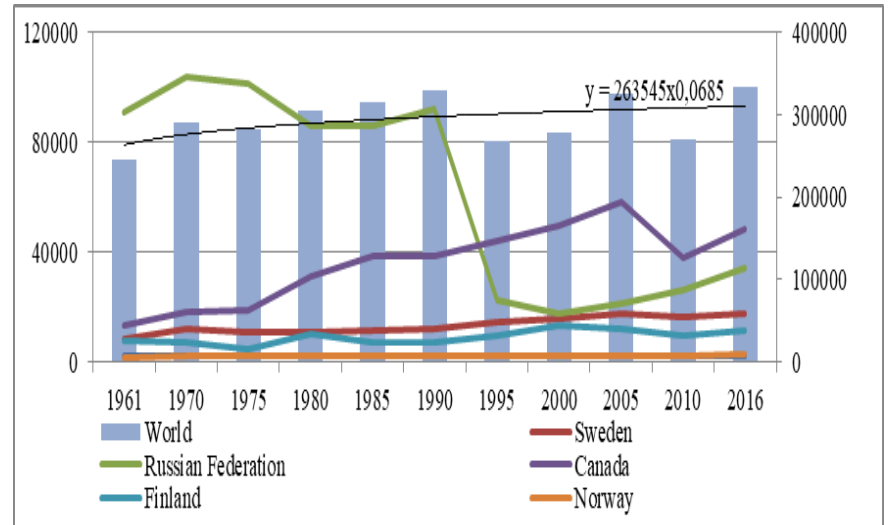

Fig. 3.Dynamics of sawn timber

The northern countries registered a negative trend in advanced processing technologies output, which is connected with some manufacturing operations being shifted to Asia [12]. For instance, the fibre production share in the global output decreased by a factor of 2.7 from 27 per cent in 1961 to 10.5 in 2016. A similar trend can be observed in paper and cardboard production: in 1961 the four countries' share was around 18 per cent of the world's total production in 2016 it was 7.7 per cent.

The northern forest industry's position in the global market depends not only on production output, but also on exports and the degree to which other countries' needs in timber products are met. The leading exporter of timber products among the analysed northern countries is Canada, which is outperformed by Sweden and Finland in paper and cardboard supplies to the global market (Table 2). These countries supply the external markets with large volumes of chemical wood pulp.

TABLE III. SAWN TIMBER EXPORTS

\begin{tabular}{|c|c|c|c|c|c|c|c|c|c|c|c|}
\hline $\begin{array}{c}\text { Expor } \\
\mathbf{t} \\
\text { Value } \\
(\mathbf{1 0 0 0} \\
\text { US\$) } \\
\end{array}$ & 1961 & $\begin{array}{l}1970 \\
\end{array}$ & 1975 & $\begin{array}{l}1980 \\
\end{array}$ & 1985 & 1990 & 1995 & 20000 & 2005 & 2010 & 2016 \\
\hline $\begin{array}{c}\text { Finlan } \\
\text { d }\end{array}$ & 671 & 1220 & 2254 & 5477 & 4614 & $\begin{array}{l}9407 \\
\end{array}$ & 11973 & 10974 & 12102 & 13161 & ${ }^{11823}$ \\
\hline $\begin{array}{c}\text { Canad } \\
\text { a }\end{array}$ & 1268 & 2745 & 4890 & 10544 & 11225 & 17895 & 27815 & 27694 & 29440 & 21258 & 22080 \\
\hline $\begin{array}{c}\text { Swede } \\
\text { n }\end{array}$ & 584 & 1554 & 3437 & 5644 & 4990 & 9730 & 111598 & 10130 & 13219 & 15289 & 12483 \\
\hline $\begin{array}{c}\text { Norw } \\
\text { ay }\end{array}$ & 153 & 299 & 2254 & 960 & 811 & 1599 & 23388 & 1626 & 1896 & 1845 & 1364 \\
\hline Russia & 329 & 840 & 1863 & 2703 & 2688 & 3035 & 4060 & 3798 & 7689 & 8598 & 8872 \\
\hline $\begin{array}{c}\text { The } \\
\text { World }\end{array}$ & 5157 & 12667 & 26000 & 56651 & 50658 & 10206 & 17741 & 1 & 187635 & 202238 & \\
\hline $\begin{array}{l}\text { The } 5 \\
\text { countr } \\
\text { ies } \\
\text { collect } \\
\text { ively }\end{array}$ & 3005 & 6658 & 14698 & 25328 & 24288 & 41666 & 57784 & 542222 & 664346 & 60151 & 56622 \\
\hline $\begin{array}{l}\text { The } \\
\text { five } \\
\text { countr } \\
\text { ies' } \\
\text { share }\end{array}$ & 58.3 & 52.6 & 56.5 & 44.7 & 47.9 & 41.6 & 39.2 & 37.4 & 34.3 & 27.1 & 24.9 \\
\hline
\end{tabular}


All things considered, in such northern countries as Norway, Finland, Sweden, and Canada, the timber industry remains what constitutes their internationally marketed specialization, generating currency revenues and the proceeds from timber products sales. For this reason, these nations have been focusing a lot over the recent decades on ways to perfect the management and the production patterns within their timber industries.

In the export breakdown of Finland, the top positions are wood and paper-based products, ranking Finland as a major player in the international division of labour and in the global trade. Finnish harvesters annually produce from 32 to 45 million cubic metres of wood. With a leading position on the global markets of sawn timber, plywood, wood-based products, cardboard, and paper pulp, Finland is ranked the third after Russia and Canada. Its timber industry accounts for ca.5 per cent in its GDP. In the nation's total industrial output, the timber industry has a share of 20 per cent. Identical is its share in Finland's export revenues. Since forests constitute Finland's most valuable natural resource, the government takes an active part in promoting the timber industry. Jointly with private investors, it has upgraded its forest management to an advanced, cluster-based model. Among the economic goals successfully achieved are:

- science development towards higher forest products output;

- a series of large-scale, competitive manufacturers operating the advanced wood processing technologies;

- production flows to make Finland's timber industry highly performing and eco-safe;

- a road network for optimized harvesting operations; and

- improved mechanical engineering for timber industry.

The performance demonstrated by Finland's forest clusters is a real-life example of how the efficient use of forestries can combine with recent know-hows to benefit not only the industry players, but also the entire country [3].

Unlike the majority of timber producing nations, Sweden boasts a stably growing size of its forested area as its legislation prescribes that forest regeneration dominates over harvesting. As a result, Sweden's current forest area is twice bigger than one hundred years ago, its timber industry making a tangible contribution to the nation's economy. To give you some figures: forest products account for 15 per cent in Sweden's exports and 4 per cent in its GDP. In the context of the globally growing demand in eco-friendly forest products, there appeared in Sweden a series of advanced timber producing and processing technologies. Significant progress has been achieved by Sweden also in forest products certification. Its timber industry cluster comprises forestharvesting, pulp-and-paper, and wood-working industries that are maintained by a total of 7,000 businesses. In 1997, Swedish government allocated 45 million US Dollars to streamline its timber industry, skills of timber industry personnel, and management.

In Canada, the timber industry is the largest taxpayer. Forested is more than 50 per cent of Canada's land area. Forests and forest management are the responsibility of Canada's Ministry for Natural Resources and Canadian Forest Service. The former is the voice for the nation's natural resources and the latter for its forest policy. While the tasks of cluster engagement and policy implementation lie with provinces and municipalities, the body responsible for coordinating the real-life forest strategies is Canada's National Research Council. To support its forest clusters, Canadian government offers schemes to foster their investmentdependent portfolios; help woodworking and related businesses enter other countries' markets; regulate employment market; attract investors to promising R\&D projects, while also focusing on dedicated training programmes [13].

Our analysis of the best forestry management practices available in the overseas countries has shown the trend towards innovation-driven models. In the case of timber industry, the innovation-driven model basically relies on two strategies. One of them comes down to innovation-driven technologies with focus on multi-faceted use of forests and the ensuing links between wood-producing businesses. To achieve them, areas are tasked to create local (regional or municipal) associations of big and medium businesses with members representing institutional investors and/or governmental bodies. The partnership relations between the government and the big businesses (private-public partnerships) are seen as a tool to speed up the concentration of production and as an essential premise for further growth of the industry. Beneficial are they also for small and medium businesses, especially in such segments as forest regeneration; forest inventory; lowrise housing construction in logging camps; transportation services; and procurement, creating more jobs and selfemployment opportunities for remoter, forest-dependent communities. The other strategy within the innovation-driven model limits the domain of the administrative forestry enterprises to forest management only, leaving a certain portion of the operational functions - contact-based, within the framework of a public-private partnership - to private companies for them to have a wider scope of intermediate felling and forest regeneration operations. Lastly, there exists one more strategy which is widely operated by the overseas countries to ensure the innovation-driven nature of their timber industry. Targeting multi-faceted use of wood, lower loss of wood raw material, and almost zero-waste production, it seeks to ensure that harvesting and processing are done by larger forest businesses and that harvesting operations combine with forest management which is done by smaller forest businesses.

With this strategy it is possible to achieve economy of scale, big investment opportunities, higher public employment, and better operational cost-efficiency as a result of hiring of smaller businesses. What distinguishes all these 
strategies is the combination principle. Common to all of them is the purpose to enhance the vertical integration of harvesting workflows, woodworking operations, and forest regeneration in the variety of their forms and scopes [14]. Given the progress is achieved by timber industries in the overseas counties, it is expedient to formulate a set of tasks that look relevant for the Russian timber industry clusters despite the fact that they are yet to be tackled abroad [2]. These tasks come down to:

- eliminating the discrepancy between the unsustainable forest exploitation and the forest management strategy;

- continuous perfecting of the cutting methods towards higher efficiency and forest plantations safety, that would take into account the local forest growth conditions and environment;

- multi-faceted use of all forest resources, including high- and low-grade wood and wood wastes;

- continuous streamlining of the exports towards higher content of high added value products.

\section{CONCLUSION}

In spite of the global timber market fluctuations that have been in place since 1961, and the cyclic, volatile nature of the pricing policy for timber products, the northern countries have achieved a sustainably performing timber industry. Their efforts to streamline their timber industries targeted and revolved around cluster-based, innovation- and investmentdriven scenarios that are still maintained in the northern countries due to the competitive financial performance of the their forest clusters that encompass the majority (more than 80 per cent) of the operating timber-related businesses [2]

Therefore, relying on overseas countries' experience in developing the timber sector, it seems possible to set primary tasks, which should be tackled by the Russian regional strategies and development programmes for the timber sector:

- enhancing the vertical integration of harvesting workflows, woodworking operations, and forest regeneration in the variety of their forms and scope, based on private-public partnerships as well;

- eliminating the discrepancy between the unsustainable forest exploitation and the forest management strategy gradually;

- modernizing the timber sector infrastructure and facilities in terms of technologies in an accelerated way;

- $\quad$ streamlining of exports towards higher content of high added value products.

As the experience of foreign countries shows, high competitiveness and stable economic growth provide, first of all, the factors that stimulate the spread of new technologies.
Given that modern competitive advantages are almost entirely due to the advantages in production technology, management, organization of promotion of goods, the successful development of the competitiveness of the economic system is possible with the integrated use of the theories of the cluster mechanism and modern concepts of innovative development. In this regard, many countries are increasingly using the cluster approach in support of the most promising areas and forms of entrepreneurship, in the formation and regulation of national innovation systems.Accordingly, developing the strategy and programmes for the Russian timber sector clustering should focus on these issues, in particular, while studies of the theoretical and conceptual basis of the northern countries' timber sectors development will assist in identifying methodology to be applied.

\section{Acknowledgment}

Researches is executed at financial support RFBR, the Russian Federation in the framework of research project No. 18-010-00147 "Theoretical and methodological approaches of functioning of territorial and production of forest cluster as an instrument of spatial development of the Russian Federation".

\section{References}

[1] Forest Products Annual Market Review 2012-2013. Geneva: UNECE FAO, 2013, pp. 120-130.

[2] Forest products annual market review 2015-2016. Geneva: UN., 2017, pp. $165-173$.

[3] Y. Blam, L. Mashkina, T. Babenko, \& O. Yermolaev, The timber sector in the context of the global industry. ECO, 11, 2013, pp. 26-44

[4] The Russian forest sector development forecast till 2030. Food and Agriculture Organisation of the United Nations, 2012, pp. 90-110.

[5] FAOSTAT ForesSTAT. Retrieved from http://faostat.fao.org/

[6] A. Makarenko, The Northern Region's forest economy and use. Arkhangelsk, Russia: Severnoe kraevoe izdatelstvo, 1931, pp..58-95.

[7] G. Preshkin, "The analysis of economic factors establishing forest resources cost", Lesnoi zhurnal, vol.1, pp.111 - 125, 2011.

[8] V. Mosyagin, "Price analysis by means of elimination methods", Izv. SPb LTA im. M.S. Kirova, vol. 203, pp. 175-182, 2013.

[9] O.Sushko, "The Current State of the timber sector in the global market globalization", Vestnik Severnogo (Arkticheskogo) federalnogo universiteta imeni M.V. Lomonosova, vol. 6, pp. 126-134, 2014.

[10] Forest Products Annual Market Review 2012 - 2013, 2013. Retrieved from http://www.unece.org /fileadmin/DAM/timber/publications/ R_EFSOS.pdf

[11] O. Sushko, A. Plastinin, "The analysis and forecast of pulp and paper products prices for Russian enterprises and the global market", Moscow: Problemy prognozirovaniya, vol. 4, pp. 43-47, 2015

[12] European forest sector outlook study. Geneva: UN, pp. 250-290, 2015.

[13] F. Schmithüsen, F. Hirsch, "Private forest ownership in Europe", Geneva: the United Nations, pp. 256-275, 2010.

[14] M. Khvesik, A. Shubaliy, "Arranging the system of integrated management of the timber sector effectiveness", Lesnoi zhurnal, vol. 2 (338), pp. 130 - 143, 2014. 